\title{
SUNRAYCE 93: WORKING SAFELY WITH LEAD-ACID BATTERIES AND PHOTOVOLTAIC POWER SYSTEMS
}

M. P. DePhillips, P. D. Moskowitz and V. M. Fthenakis

$$
\begin{gathered}
\text { FECE: VED } \\
\text { JUL OR } 1933 \\
\text { OSTI }
\end{gathered}
$$

\footnotetext{
BIOMEDICAL AND ENVIRONMENTAL ASSESSMENT GROUP
}

ANALYTICAL SCIENCES DIVISION

DEPARTMENT OF APPLIED SCIENCE

BROOKHAVEN NATIONAL LABORATORY UPTON, LONG ISLAND, NEW YORK 11973 


\section{DISCLAIMER}

This report was prepared as an account of work sponsored by an agency of the United States Government. Neither the United States Government nor any agency thereof, nor any of their employees, makes any warranty, express or implied, or assumes any legal liability or responsibility for the accuracy, completeness, or usefulness of any information, apparatus, product, or process disclosed, or represents that its use would not infringe privately owned rights. Reference herein to any specific commercial product, process, or service by trade name, trademark, manufacturer, or otherwise does not necessarily constitute or imply its endorsement, recommendation, or favoring by the United States Government or any agency thereof. The views and opinions of authors expressed herein do not necessarily state or reflect those of the United States Government or any agency thereof.
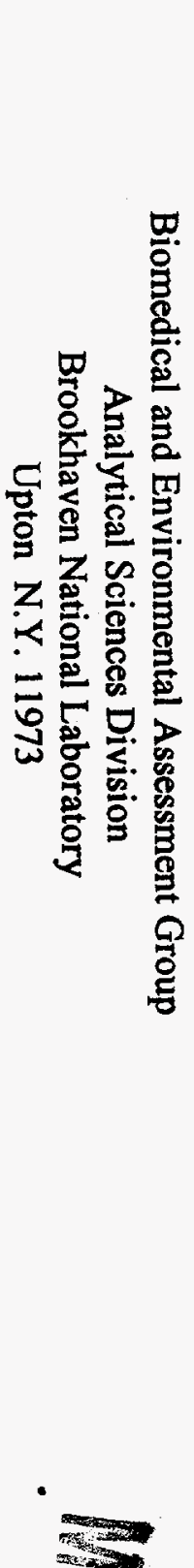


\section{TABLE OF CONTENTS}

1. INTRODUCTION 1

2. COMPONENTS

2.1 Batteries........................................ 1

2.2 Photovoltaic Modules........................... 2

3. SAFETY.......................................... 2

3.1 Sulfuric Acid ................................. 3

3.1.1 Personal Protective Equipment......... 3

3.1.2 Preparing Electrolyte Battery Transport .................... 4

3.1.3 Battery Transport....................... 4

3.1.4 Accident Response ..................... 4

3.2 Hydrogen ....................................... 5

3.2.1 General Operations ................... 5

3.2.2 Battery Recharging..................... 6

3.2 .3 Ventilation ........................... 7

3.3 Electrical....................................... 7

3.3.1 Risks On-Board Vehicle............... 7

3.3.2 External Risks ......................... 8

3.3.3 Risk Management Strategies............ 9

4. GENERAL MAINTENANCE ....................... 10

4.1 Troubleshooting ............................. 10

4.1.1 Hydrometer Check.................. 10

4.1.2 Voltmeter Check ..................... 11
5. CONCLUSION.

\section{TABLES}

1. Lead-Acid Storage Battery Components and Their Use 2

2. Recommended Material for Gloves and Aprons........ 3

3. Sulfuric Acid - Safety and Response Chart............. 5

4. Hydrogen - Safety and Response Chart ...............6

5. Physiological Effects of DC Currents at Ambient Temperature 8

6. Electrical Shocks - Safety and Response Chart ......... 9

7. Safety Equipment Checklist 11

\section{ACKNOWLEDGMENT}

The authors acknowledge Paul Basore - Sandia National Laboratories, Lewis Jacobson - Brookhaven National Laboratory, Richard King - U.S. Department of Energy, and Cecile Leboeuf - National Renewable Energy Laboratory for their helpful comments. 


\section{DISCLAIMER}

Portions of this document may be illegible electronic image products. Images are produced from the best available original document. 


\section{INTRODUCTION}

The U.S. Department of Energy (DOE) is sponsoring SUNRAYCE 93 to advance the technology and use of photovoltaics and electric vehicles. Participants will use cars powered by photovoltaic modules and lead-acid storage batteries. This brochure, prepared for students and faculty participating in this race, outlines the health hazards presented by these electrical systems, and gives guidance on strategies for their safe usage.

At the outset, it should be noted that working with photovoltaic systems and batteries requires electric vehicle drivers and technicians to have "hands-on" contact with the car on a daily basis. It is important that no one work near a photovoltaic energy system or battery, either in a vehicle or on the bench, unless they familiarize themselves with the components in use, and know and observe safe work practices including the safety precautions described in the manuals provided by the various equipment vendors and this document.

\subsection{COMPONENTS}

All personnel working with the electric vehicle, whether in the lab, in the chase car, or in the car itself, must be familiar with the basic components of a lead-acid battery and a photovoltaic system.

\subsection{Batteries}

The electrochemical components of lead-acid batteries are usually lead dioxide, $\left(\mathrm{PbO}_{2}\right)$ in the positive electrode (cathode), spongy lead in the negative electrode (anode), and an electrolyte bath (dilute sulfuric acid, $\mathrm{H}_{2} \mathrm{SO}_{4}$ ). The lead dioxide can have several crystal forms and is seldom found with an exact formula. The electrolyte is usually discussed in terms of its specific gravity and is mixed by adding concentrated sulfuric acid to water $\left(\mathrm{H}_{2} \mathrm{SO}_{4}+\mathrm{H}_{2} \mathrm{O}\right)$. There are many types of lead acid batteries produced; however, all have certain features in common. One is the open-circuit cell electromotive force $(\mathrm{emf})$, which exists between a positive and a negative electrode when the two are immersed in sulfuric acid electrolyte. This value is nearly independent of the quantities of lead peroxide, lead or electrolyte present and does not vary significantly with temperature and sulfuric acid concentration. 
Table 1 Lead-Acid Storage Battery Components and Their Use

\begin{tabular}{|c|l|}
\hline Plate Grid & $\begin{array}{l}\text { Supporting framework for the active materials of the } \\
\text { plates. They also conduct the current to and from the } \\
\text { active material plates. Made from a lead alloy }\end{array}$ \\
\hline $\begin{array}{c}\text { Pusitive and } \\
\text { Pegative Plates }\end{array}$ & $\begin{array}{l}\text { Plate grid with a paste consisting of a mixture of lead } \\
\text { oxide, sulfuric acid and water. The negative plates } \\
\text { have an "expander" added to the paste which prevents } \\
\text { the negative material from contracting and becoming } \\
\text { inactive. }\end{array}$ \\
\hline Separators & $\begin{array}{l}\text { Thin sheets of electrically insulated porous material } \\
\text { used as spacers between the plates to prevent short } \\
\text { circuits within the cells. Fine pores allow ionic flow in } \\
\text { the electrolyte between the positive and negative plates. }\end{array}$ \\
\hline Elements & $\begin{array}{l}\text { A stack of alternate positive and negative plates and } \\
\text { separators. }\end{array}$ \\
\hline Cell Connectors & $\begin{array}{l}\text { Used to connect element's terminal posts in a series } \\
\text { over or through the cell partitions. }\end{array}$ \\
\hline Cell Covers & $\begin{array}{l}\text { Usually made of plastic and are one-piece construction. } \\
\text { The outside case designed to withstand temperature } \\
\text { extremes, resist damage by mechanical shock in rough } \\
\text { road service and resist acid absorption and chemical } \\
\text { attack. }\end{array}$ \\
\hline Container & $\begin{array}{l}\text { Prevents any leakage of acid. } \\
\text { Cell and not be pumped from the battery by the eseapiag } \\
\text { gas. }\end{array}$ \\
\hline Cover to Container Plugs & $\begin{array}{l}\text { Allows gas to escape from the battery. Also allows any } \\
\text { Seal }\end{array}$ \\
\hline
\end{tabular}

\subsection{Photovoltaic Modules}

The photovoltaic effect is the basis behind the conversion of light to electricity in photovoltaic, or solar cells. Individual solar cells are approximately $100 \mathrm{~cm}^{2}$ in size and have a nominal voltage of about $0.5 \mathrm{~V}$. In order to increase the voltage, single solar cells are electronically tied together. Cells connected in series form strings, and strings connected in series form modules. Modules can be connected together in series or parallel to form a panel. These panels then can be arranged in a variety of different configurations (e.g., parallel or series) to form an array.

In a solar vehicle, these arrays may vary with each vehicle design type. Many of these designs will be displayed at SUNRAYCE 93 including unified body and solar array, separate body and solar array, and catamaran type. All arrays attempt to optimize energy collection, and maximize power output to keep the vehicle's battery in a high state of charge.

\subsection{SAFETY}

The principal safety concerns in working with an electric vehicle for SUNRAYCE 93 are associated with the handling of lead-acid batteries, which contain sulfuric acid and can emit a potentially explosive mixture of hydrogen and oxygen. There is also a possible risk of receiving an 
electrical shock from both the photovoltaic modules and the batteries.

\subsection{Sulfuric Acid.}

Lead-acid batteries contain sulfuric acid which can burn skin and clothing, seriously impair eyesight and may be fatal if swallowed. Precautions to be taken in handling and responding to spilled electrolyte include; wearing personal protective equipment, chemical resistant gloves, safety goggles, face shield; use of neutralizing fluid and clean water in the event of spill; and constant ventilation of the work and battery storage areas.

\subsubsection{Personal Protective Equipment}

It is important to wear the proper personal protective equipment (PPE), to guard against possible burns resulting from spilled or splashed electrolyte. It is essential to wear this attire when; preparing electrolyte, filling the batteries with electrolyte, carrying a battery, conducting battery tests that include exposure to electrolyte, and responding to an accident in which a battery may have been damaged.

PPE includes a full face shield; chemical resistant safety goggles; chemical resistant gloves and a splash apron with arm protectors. Table 2 presents a list of materials approved for use with sulfuric acid published by DOE (Guidelines for the Selection of Chemical Protective Clothing, 1992).
Table 2. Recommended Material for Gloves and Aprons

\begin{tabular}{|c|c|c|}
\hline MATERIAL & GLOVES & APRON \\
\hline BUTYL & $\%$ & 6 \\
\hline CPE & $\%$ & \\
\hline PE & $\%$ & \\
\hline BARRICADE & & 3 \\
\hline CHEMERAL MAX & $\%$ & $\%$ \\
\hline GORE-GARD & & $\%$ \\
\hline GORE-TEX & & 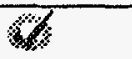 \\
\hline NEOP & & $\%$ \\
\hline PTFE TEFLOW & & 6 \\
\hline PVC & & \% \\
\hline SARANEX23p & $\%$ & क \\
\hline TRELLCHEM HPS & & 6 \\
\hline CHECKMATE & $\%$ & \\
\hline CHEMTUFF & $\%$ & \\
\hline CPF III & $\%$ & \\
\hline INTERCEPTOR & $\%$ & \\
\hline POLYURETHANE & 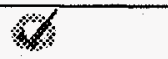 & \\
\hline NEOP/BUTYL & 6 & \\
\hline
\end{tabular}




\subsubsection{Preparing Electrolyte}

Most batteries suitable for SUNRAYCE 93 will come with electrolyte in the battery. If, however, it becomes necessary to prepare electrolyte, do so in a well ventilated area (see section 3.2.3) with an accessible safety shower and eye bath. Sulfuric acid reacts violently with water, therefore, always pour the concentrated acid slowly into the water; not the water into the acid, until the desired specific gravity is reached. Heat is generated when the acid is mixed with the water so add only small amounts of acid slowly while stirring. Allow this solution to cool if noticeable heat develops. Use non-metallic receptacles and funnels. Do not store acid in excessively warm locations or in direct sunlight. Do not smoke, avoid breathing vapor and wear the PPE as described in the section 3.1.1.

\subsubsection{Battery Transport}

Use extreme care when relocating a battery to avoid spilling or splashing the electrolyte. When handling a plastic cased battery, excessive pressure placed on the end walls could cause electrolyte to spew through the vents. Therefore, always use a battery carrier or lift them with your hands on opposite corners. If electrolyte is spilled or splashed on clothing or the body, the area should be neutralized immediately with a solution of baking soda and water (one $\mathrm{kg}$ per liter of water), and then thoroughly rinsed with clean water.

\subsubsection{Accident Response}

Under routine driving conditions the potential for contact with electrolyte is very small; however, in a severe accident it is possible for a driver to come into direct contact with spilled electrolyte from the vehicle's battery. Thus, it is strongly suggested that in a race environment, the driver should wear a long sleeve shirt and long pants. Gloves should be kept in the car in case of an emergency.

In an accident when electrolyte could be spilled, a neutralizing solution and plenty of clean water should be brought to the scene. All responding personnel should be wearing appropriate PPE (see section 3.1.1); spectators and other nonessential personnel should be immediately cleared from the area. Any spilled electrolyte should be neutralized and then rinsed with clean water. Each chase car should carry approximately $17 \mathrm{~kg}$ of baking powder, enough to neutralize a complete discharge of electrolyte from the battery array. If the electrolyte is spilled indoors, immediately evacuate the area and call for a HAZMAT team.

Electrolyte splashed into the eyes is extremely dangerous. If this should happen, force the eye open and flood it with cool, clean water for approximately fifteen minutes. A doctor should be called immediately when the accident occurs and "on-the-spot" medical attention given if possible. If a doctor cannot come to the scene of the accident immediately, follow his instructions concerning actions to take. If electrolyte is taken internally, drink large quantities 
of water or milk. Follow with milk of magnesia, beaten egg or vegetable oil. Transport the patient to a hospital as soon as possible. Table 3 presents a quick reference guide for proper safety and response regarding sulfuric acid.

Table 3. Sulfuric Acid - Safety and Response Chart

\begin{tabular}{|c|}
\hline SULFURIC ACID \\
\hline Acute Effects \\
\hline - May be fatal if swallowed. \\
\hline - Harmful if inhaled or absorbed through the skin. \\
\hline - Causes burns. \\
\hline $\begin{array}{l}\text { - Material is extremely destructive to tissue of the mucous } \\
\text { membranes and upper respiratory tract, eyes and skin. }\end{array}$ \\
\hline $\begin{array}{l}\text { - Inhalation may be fatal as a result of spasm, } \\
\text { inflammation and edema of the larynx and bronchia, } \\
\text { chemical pneumonitis and pulmonary edema. }\end{array}$ \\
\hline $\begin{array}{l}\text { - Symptoms of exposure may include burning sensation, } \\
\text { coughing, wheezing, laryngitis, shortness of breath, } \\
\text { headache, nausea and vomiting. }\end{array}$ \\
\hline : $\quad$ Response to Spills \\
\hline - Evacuate area. \\
\hline $\begin{array}{l}\text { - Cover with neutralizing solution, (e.g., baking soda } \\
\text { solution). Place in covered containers using non- } \\
\text { sparking tools and transport outdoors. }\end{array}$ \\
\hline $\begin{array}{l}\text { - Ventilate area and wash spill site after material pickup is } \\
\text { complete. }\end{array}$ \\
\hline First Aid \\
\hline
\end{tabular}

- In case of contact, immediately flush eyes or skin with copious amounts of water for at least 15 minutes while removing contaminated clothing and shoes.

- Assure adequate flushing of the eyes by separating the eyelids with fingers.

- If inhaled, remove victim to fresh air. If not breathing give artificial respiration. If breathing is difficult, give oxygen.

- If swallowed, drink large amounts of milk or water, provided victim is conscious.

- Call a physician immediately.

- Wash contaminated clothing before reuse.

- Discard contaminated shoes.

\subsection{Hydrogen}

Batteries expel explosive gases. Keep sparks, flames, burning cigarettes, or other ignition sources away at all times. Always wear appropriate PPE when working near batteries. Never lean over the battery when charging or testing a battery and avoid the direct inhalation of air proximate to a battery.

\subsubsection{General Operations}

An explosive mixture of hydrogen and oxygen gases can be produced during normal battery operation. These gases continually escape through the battery vents and may form an explosive atmosphere around the battery if ventilation 
is poor. Thus, sparks, flames or other ignition sources should be kept away from the battery system. Do not break "live" circuits at the terminals of batteries because a spark invariably occurs at the point were a "live" circuit is broken. Make certain all cable clamps or booster leads are clean and they make good connections. A poor connection can cause an electrical arc which could ignite the gas mixture and explode the battery.

Be careful that tools or other metallic objects do not fall across battery terminals or conductors. Do not smoke when working under the hood of a car or near a battery and never strike a match or bring any other flame in the vicinity of a battery. Table 4 presents a quick reference guide for proper safety and response regarding hydrogen emissions.

\subsubsection{Battery Recharging}

Recharging will cause a battery to emit potentially explosive mixtures of hydrogen gas. Even if a battery is standing idle, it will generate small quantities of hydrogen due to a self-discharge action. This gas collects in the cells and is present proximate to the batteries at all times. Therefore, keep all sources of fire (e.g., torch, match flame, lighted cigarette), and all metal objects away from the recharging area. Also, ensure that all electrical connections are secure. This will prevent sparks, resulting from loose connections or metal tools making contact between the terminals or conductors, from triggering an explosion. As always, wear appropriate PPE in case there is an explosion.
Table 4. Hydrogen - Safety and Response Chart

\begin{tabular}{|c|c|}
\hline & HYDROGEN \\
\hline - An odorless, colorless, tasteless gas. & An odorless, colorless, tasteless gas. \\
\hline & $\begin{array}{l}\text { Dangerous fire and explosion hazard when exposed to } \\
\text { heat or flame. }\end{array}$ \\
\hline & $\begin{array}{l}\text { Fire Fighting Media } \\
\end{array}$ \\
\hline & $\begin{array}{l}\text { Move container (i.e., battery) from fire if you can do so } \\
\text { without risk. }\end{array}$ \\
\hline & $\begin{array}{l}\text { Apply cooling water to sides of containers that are } \\
\text { exposed to flames until well after fire is out. }\end{array}$ \\
\hline & $\begin{array}{l}\text { Cool containers with flooding amounts of water, apply } \\
\text { from as far a distance as possible. }\end{array}$ \\
\hline & Avoid breathing vapors, work upwind. \\
\hline & $\begin{array}{l}\text { First Aid } \\
\end{array}$ \\
\hline & $\begin{array}{l}\text { Remove victim from exposure area to fresh air } \\
\text { immediately. }\end{array}$ \\
\hline & If breathing has stopped, give artificial respiration. \\
\hline & $\begin{array}{l}\text { Maintain airway and blood pressure and administer } \\
\text { oxygen if available. }\end{array}$ \\
\hline & Keep affected person warm and at rest. \\
\hline & Get medical attention immediately. \\
\hline
\end{tabular}

Vent caps should be left on the battery during charging. Flame arresters used in most modern vent caps are designed to reduce the possibility of the battery being exploded by an external spark. If violent gassing or spewing of electrolyte occurs during recharging, reduce or temporarily halt the charging. 
If clamp-type connectors are used when charging, do not touch the charger lead when the charger is "ON". This could break a connection at the battery terminal, creating a spark which could ignite the explosive gases in the battery. As mentioned, never break a "live" circuit at the battery terminal for the same reason. Always turn the charger "OFF" before connecting or removing a charger lead from the battery.

If working with a recombinant (sealed lead-acid) battery, a temperature compensating recharger is needed to prevent the battery from overheating and ruining the battery. When recharging a sealed battery, it is vital that a precisely controlled charging voltage be used. This will help prevent overheating of the battery during recharge.

\subsubsection{Ventilation}

When preparing electrolyte and maintaining batteries, continuous ventilation should be maintained. In an ideal scenario, room air should be exhausted to a remote location. Exhaust systems should be designed to protect people in the surrounding area from contaminated air. With regard to ventilation within the car, race rules state that the battery system onboard the vehicle must be equipped with a forced ventilation system rated to at least $283 \mathrm{l} / \mathrm{min}$. The ventilator must operate whenever the battery system is electrically connected to the solar car, sending exhaust to the exterior of the vehicle.

\subsection{Electrical}

There is a risk of electric shock when working with electrical systems such as photovoltaic modules and leadacid batteries. In general, when working around electrical systems, keep hands and feet dry, wear rubber soled shoes, use insulated tools and properly ground all live units. Prevent all unauthorized people from touching the photovoltaic modules.

\subsubsection{Risks On-Board Vehicle}

There is a potential hazard of electric shock while working on an electric vehicle. Although the photovoltaic array and battery system in the solar car are of relatively low voltage, an electric shock resulting from these systems could be very dangerous. A typical array of solar cells could generate voltages, at the main power bus, in the range of 50 to $150 \mathrm{~V} \mathrm{DC}$. The accessory power bus is $12 \mathrm{~V} \mathrm{DC}$, similar to combustion engines.

In general, DC voltage is not considered as harmful as the corresponding $\mathrm{AC}$ voltage because it does not produce strong muscle contractions which may "freeze" a victim and result in longer exposure. Nevertheless, contact with DC circuits can be very hazardous as shown in Table 5, especially with a highly conductive media (e.g., wet skin). Contact with an energized circuit of the main power bus could produce effects ranging from painful shock to death. At the voltages present in the accessory bus, the hazard would likely 
Table 5 Physiological Effects of DC Currents At Ambient Temperature $\left(82^{\circ} \mathrm{F}\right)$

\begin{tabular}{|c|c|c|c|}
\hline $\begin{array}{l}\text { Voltage } \\
\text { (V) }\end{array}$ & $\begin{array}{c}\text { Body } \\
\text { Impedance } \\
\text { (ohm) }\end{array}$ & $\begin{array}{c}\text { Current } \\
\text { passing } \\
\text { through } \\
\text { body }(\mathrm{mA})\end{array}$ & $\begin{array}{c}\text { Physiological } \\
\text { Effects* }\end{array}$ \\
\hline 17.5 & 500 & 35 & A \\
\hline 35 & 500 & 70 & B \\
\hline 53 & 500 & 106 & B \\
\hline 70 & 500 & 141 & B \\
\hline 88 & 500 & 176 & C \\
\hline 106 & 500 & 211 & $C, D$ \\
\hline \multicolumn{4}{|c|}{$\begin{array}{l}\text { * A: Shock is painful but not fatal. } \\
\text { B: Shock is painful and could produce temporary } \\
\text { respiratory arrest or cause unconsciousness; death is possible } \\
\text { but highly unlikely; burns are also possible. } \\
\text { C: This effect is above the } 0.5 \% \text { fibrillation (i.e., an } \\
\text { irregular heartbeat) threshold for a } 50 \mathrm{~kg} \text { person; death could } \\
\text { occur for members of this } 50 \mathrm{~kg} \text { group; cardiac arrest, } \\
\text { unconsciousness, secondary injuries and contact burns can } \\
\text { also occur. } \\
\text { D: This effect is at or above the } 0.5 \% \text { fibrillation } \\
\text { threshold for a } 70 \mathrm{~kg} \text { person; (death may occur for members } \\
\text { of this } 70 \mathrm{~kg} \text { group); cardiac arrest, unconsciousness, } \\
\text { secondary injuries and contact burns can also occur. }\end{array}$} \\
\hline
\end{tabular}

be limited to a painful shock. A photovoltaic array can also be a hazard under indoor lighting, so remember to always keep a safe distance away. from the energized circuit or deenergize the circuit if it is necessary to work with or near the unit.

\subsubsection{External Risks}

During pre-race activities, batteries may be recharged by an $\mathrm{AC}$ powered battery recharger, rather than a photovoltaic module. Before any recharger is used, the operator should first read the owner's manual and any other documentation that comes with the particular battery charger being used.

The following recharging procedures should greatly reduce any risk of receiving electrical shock while recharging:

1. Turn the charge rate switch and timer to the "OFF" position before connecting the leads to the battery.

2. Connect the charger leads to the battery; red positive $(+)$ lead to positive terminal and black negative (-) lead to negative terminal. Rock the charger lead clamps to make certain a good connection has been made.

3. Set the electric timer to the desired charging time. Turn on the charger and slowly increase the charging rate until the desired ampere value is reached. Do not charge in the red zone. 
4. Make certain that charger is "OFF" (preferably unplugged) before removing charger leads from battery.

\subsubsection{Risk Management Strategies}

The following strategies will greatly reduce the risk of receiving an electrical shock while working with low voltage electrical systems associated with solar vehicles. Always assume that all circuits are electrically energized and keep all unauthorized personnel at a safe distance from the unit. All SUNRAYCE 93 participants should undergo formal training in the hazards presented by DC circuits and in proper procedures for working with live circuits (i.e., "hot" environment).

During maintenance operations, personnel should electrically isolate themselves from energized circuits by using low voltage gloves, insulated tools, a one-hand maintenance technique, use of electrical insulating materials over areas not being worked on, and a physical clearance around work areas with energized circuits. It should be noted the materials recommended for gloves in Section 3.1.1 are insulators and should protect against the low voltage present during recharging activities. They should not, however, substitute for electrical gloves when working with higher voltage circuits. All potentially conductive apparel such as jewelry, watch bands, bracelets, and/or rings should not be worn. In the confined space of the electric vehicle, special care should be taken to avoid inadvertent contact with the energized parts (e. g., ensure that all moving parts are

Table 6. First Aid For Electrical Shock Victims

\begin{tabular}{|c|}
\hline ELECTRIC SHOCK: SAFETY AND RESPONSE CHART \\
\hline Ensure That Victim Is No Longer In Contact With The \\
Energized Circuit
\end{tabular}


secured). The vehicles primary electrical system should not be grounded to the vehicles frame. All supportive materials used for array support should be made of an insulating material (e.g., plastics) not a conductive material (e.g., graphite epoxy). This greatly reduces the risk of both electrical shock and short circuits. The system should be tested frequently to ensure isolation from the frame.

Finally do not touch, or allow spectators to touch, the photovoltaic modules. If the surface of the modules are not properly insulated they could be energized. Table 6 presents first aid procedures that should be administered in the event of an electrical shock.

\subsection{GENERAL MAINTENANCE}

Proper battery maintenance is the best prevention against accidents and battery failure. The following sections provide simple, preventative maintenance procedures that should be performed on a regular basis. Safety precautions for procedures are also presented.

\subsection{Troubleshooting}

If a vehicle is not performing satisfactorily, and battery failure is suspected, test each battery to confirm that the problem is not in the charger motor/controller and interbattery connections. Connections which show signs of corrosion (white deposits) are usually the result of electrolyte flowing from the cells due to over-watering. If corrosion is present, the connections should be removed, but only after making sure all vehicle switches are turned off, and the corrosion has been neutralized with a baking soda solution. The baking soda solution should be maintained on the terminal area until the "fizzing" stops. Battery posts and cable lugs should then be wire-brushed to shiny metal before reassembling. Before the cables are reconnected, the area should be rinsed with clean water and the vent caps should be tightened.

\subsubsection{Hydrometer Check}

The specific gravity of each cell of a battery is measured by using a hydrometer. A hydrometer is a bulb shaped syringe which will extract electrolyte from a cell. A glass float in the hydrometer barrel is calibrated to read in terms of specific gravity. A common range of specific gravity used for these floats is 1.160 to 1.325 . Bring the hydrometer to eye level (only while wearing safety goggles) and note the level. Check the owner's manual of the particular battery you are using to determine what a full charge would be (usually 1.265). If the variation between the highest and lowest cell readings in any one battery is 0.050 or more, it probably has a failing cell. When performing this test please keep in mind that sulfuric acid electrolyte is being extracted from the battery. Take care not to splash, drop or 
spill the contents of the hydrometer and return it to the battery or into a non-metallic container.

\subsubsection{Voltmeter Check}

If the top connectors are accessible, read the voltage of each cell. A variation between the highest and lowest reading of 0.050 volts or more may indicate a failing cell. If the voltage of each cell cannot be measured, test the terminal voltage of each battery. Compare the voltage of the batteries. Remember, the potential for electric shock exists any time the batteries are in a series and always exercise appropriate caution (refer to section 3.3 ).

\subsection{CONCLUSION}

SUNRAYCE 93 can be a productive and exciting way to promote the advantages of solar powered electric vehicles. To ensure that these benefits are realized, it is important that all members of the SUNRAYCE 93 team be aware of the hazards presented by the electrical systems and of the procedures and equipment needed to work safely with them. Table 7 shows a checklist of equipment needed for working safely with electric vehicles generated by photovoltaic system and lead-acid batteries.
Table 7

\section{SAFETY EQUIPMENT CHECKLIST}

\begin{tabular}{|c|c|c|}
\hline \multicolumn{3}{|c|}{$\begin{array}{l}\text { Be certain that the equipment listed below is close by the solar } \\
\text { vehicle at all times during the race. }\end{array}$} \\
\hline \multirow[t]{2}{*}{ Laboratory } & $\begin{array}{l}\text { Chase } \\
\text { Vehicle }\end{array}$ & $\begin{array}{l}\text { Solar } \\
\text { Vehicle }\end{array}$ \\
\hline & & GLOVES \\
\hline \multirow[t]{2}{*}{ 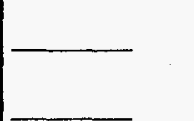 } & & SLEEVED APRON \\
\hline & & FACE SHIELD \\
\hline \multirow[t]{2}{*}{ 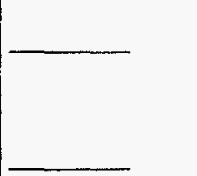 } & & $\begin{array}{l}17 \text { kgs BAKING SODA } \\
\text { POWDER }\end{array}$ \\
\hline & & SAFETY GOGGLES \\
\hline \multirow[t]{2}{*}{$\ldots$} & & FIRST AID KIT \\
\hline & & WOODEN CANE \\
\hline \multirow{3}{*}{. } & & FLARES \\
\hline & & _FLASHLIGHT \\
\hline & & LONG SLEEVE SHIRT \\
\hline _ & & LONG PANTS \\
\hline
\end{tabular}

